\title{
Colombia in the Free Trade Area of the Americas as SEEN FROM THE PRESENT*
}

José Alberto Pérez Toro**

This paper is based on chapter 6 of my Ph.D. dissertation entitled From Free Trade to Globalization. Initial Conditions for World Business Expansion and Perspectives for the 21st Century in Colombia. University of Northern Washington, 2001. Some parts of this document were presented at the 2001 meeting of the Latin American Studies Association-LASA, Washington D.C, September 6-8, 2001. Two anonymous referees made valuable comments. Este artículo se recibió el 07-11-2003 y se aceptó el 27-04-2004.

** Ph.D., University of Northern Washington, 2002; Master of Philosophy in Latin American Studies, University of Oxford, 1975; Diploma in Economic Development, University of Oxford, 1973; Ingeniero industrial, Universidad de los Andes, 1971. Profesor investigador, Universidad Javeriana, Facultad de Ciencias Económicas y Administrativas. E-mail: japerez@javeriana.edu.co 
The aim of this paper is to know, compare, contrast and evaluate the positive aspects of creating a hemispheric market, by analyzing the bilateral and multilateral agreements under negotiation, particularly the Free Trade Area of the Americas (FTAA). The theoretical framework is based on the study of historical factors characterized by institutional changes in the economic integration process of the Americas. Institutional elements refer to commerce particularities, the access to markets, the regulations on services, and investment origin and protection. They also refer to other commercial practices, such as governmental purchases, custom regulations, and the mechanisms used to solve controversies. The methodology used is the analysis of singular processes that determine a chain of facts, such as the integration schemes, which are framed in regularities like those observed in sector commercial agreements. An outstanding result is the convergence of integration processes, a necessary condition for the eventual creation of a global commerce system.

Key words: Economic integration, Free Trade Area of the Americas (FTAA), Free Trade Agreement (FTA), free trade areas, bilateral and multilateral agreements, Andean Community of Nations, MERCOSUR.

\section{Colombia en el Acuerdo de Libre Comercio de las Américas, una visión desde el presente}

El objetivo del artículo es conocer, comparar, contrastar y evaluar aspectos positivos, relacionados con la conformación de un mercado hemisférico, partiendo del marco de los acuerdos bilaterales y multilaterales en proceso de negociación, en particular el ALCA. El marco teórico se fundamenta en el estudio de las particularidades históricas que determinan puntos de partida, determinados por los cambios institucionales y por factores históricos de la real coyuntura del proceso de la integración económica en el hemisferio americano. Los elementos institucionales se refieren a las particularidades teóricos del comercio, a los temas de acceso a los mercados; las normas sobre comercio de servicios, inversión, origen y protección a la inversión. También a otras prácticas comerciales como son: las compras gubernamentales, las normas aduaneras y los mecanismos para la solución de controversias. Como marco metodológico se emplea el análisis de procesos singulares que determinan familias de hechos como son los esquemas de integración, los cuales se enmarcan en regularidades tales como los observables en las acuerdos sectoriales de comercio. Dentro de los resultados sobresale el logro de la convergencia de los procesos de la integración, condición para una eventual conformación de un sistema global de comercio.

Palabras clave: integración económica, Acuerdo de Libre Comercio de las Américas (ALCA), Tratado de Libre Comercio (TLC), áreas de libre comercio, acuerdos bilaterales y multilaterales, Comunidad Andina de Naciones, Mercado Común del Sur (Mercosur). 


\section{Introduction}

Academic analysts claim that many Latin American countries will face a substantial change in the structure of the commercial relationship with the rest of the world and in particular within the western hemisphere in the near future. Analyzing this emerging process requires a methodological approach that allows us to reveal some general consequences about a negotiated long-term course of action embedded in past multilateral, hemispheric, regional and bilateral practices framed by countrie's commercial events. Nobel laureate economist Douglas North (1998: 100) regarded the political and economic process as a consequence of institutional interaction. He claims that economic change arises from a particular path that locks into a dependence development. Historiographic analysis develops another kind of argument to relate social changes to historical times, where past events are interpreted by a careful reconstruction of reality described by the narrative, which simply helps to explain the past from the view of the present as proposed by Le Goff (1991: 27). The purpose of the methodology or even of the scientific assumptions is merely to foretell trends as being the consequences of historical laws.

Historical methodologists, in order to make a theoretical analysis of the past and to portray a real picture of the social world, attempt to understand events and their causes with the help of some social science theories. With a collection of facts that we may use to connect with models made out of selected variables, they work to help explain some historical developments. Sometimes we connect the past with the present and even the present with theoretical views to predict the future, following certain rules, as pointed out by the historical philosopher Werner Sombart. This author published an article in 1929, "Economic Theory and Economic History", suggesting that we must begin with the significance of past events in history to reveal a factual departure point to explain, for example, the nature of future behavior of variables. Carlo M. Cipolla (1991: 22), a distinguished economic historian, goes even further using this methodology, and determines that economic history differs from economics. The first discipline, economic history, deals with a great number of variables to explain the complexity of past events, while the second, economics as such, uses fewer variables to build models that have the specificity to predict some tendencies.

Regarding the stated considerations to connect historical time with future scenarios, current theoretical approaches invite us to build a hypothesis to reveal how and when economic events follow certain trends. We use this methodological approach in this paper to allow ourselves to inquire about possible integration routes that may be followed by thirty-four hemispheric nations attempting to integrate their markets into a single global one. They have followed different paths, developing the trend from unilateral acts, bilateral agreements between a selective set of hemispheric countries, and regional talks in a wider perspective of multilateral rounds.

To relate the discussion to immediate events, bilateral and multilateral commercial agreements in the hemisphere are in the plan to be considered and probably to be approved 
by the legislatures in most countries in the Western Hemisphere. For example, the United States has conducted many Trade and Investment Commission conferences with a large number of countries, and in some special cases has gone even further to impose unilateral political acts to fight against drug production and to extend commercial benefits to countries covered by this political practice. Other sets of countries, like Chile and those in Central America have negotiated bilateral trade agreements. The United States, under the extension of the Trade Preference Act-TPA, will sign with the Andean Community Countries, including Colombia, a bilateral agreement that will have repercussions in the political, social and economic life of these countries. Other nations are in the process of subscribing a multilateral agreement like the Free Trade Area of the Americas-FTAA. Some blocs like the Andean Community and Mercosur have developed particular strategies to negotiate within the hemisphere a new political Summit of the Americas agreement, which includes political and commercial negotiations, including political considerations to preserve democracy and stimulate openmarket opportunities for the commercial participants (Guilhon, 2003).

Based on these historical facts, we attempt in the first part of the paper to explore some future consequences generated by bilateral negotiations followed after some countries adopt the series of bilateral agreements. In the second part of the document, we build some general hypotheses about long-term perspectives resulting from multilateral trade agreements, where new development depends on the spread and confluence of global forces that affect world markets.

\section{Present and Future of US Trade Agreements}

The present trade activities within the Americas depend on the advancement of the bilateral trade talks that are oriented to change trade currents, after we subscribe to a bilateral agreement with the United States, as did Chile and the Central American countries. Multilateral trade agreements are considered as a different approach to confront and control world trade, which is affected by different factors, which will require some countries to rearrange certain institutions in the immediate future. Other interacting nations within the World Trade OrganizationWTO negotiated the Doha Round, following a complex interdependence approach of international relations. Here the power base seems to be considered as more complex and a more conceptually elaborate framework, as trade, investment and political interest interact within an intricate historical structure. As in the emerging global world, economic interests evolve to build a freer market and a participatory political environment, and most countries commit themselves to changing their own constitutions and economic and political practices. In the global market, the economic variables interact and generate powerful forces through which the distribution of goods and investment flows in rich and enormous volumes. Accumulated political power around this initiative will exercise a tremendous impact upon a large number of nations, where emerging forces create conflicting interests that will have to be settled. In view of this unprecedented historical development, where strong economic interests compete for expanding markets, the definitions of 
different scenarios to organize negotiations will be demanded.

The United States Congress has developed a consistent view about this emerging continental market, and has approached the understanding of this complex international relations reality, organizing itself around agreements on the convergence of these economic and political forces. The architecture through which the enlargement of a global world market takes place comes from competition itself. The leading world power sees that there exists a set of unilateral, bilateral and multilateral approaches to initiate and organize negotiations. In the emerging environment, the United States may take advantage (with other large countries) of the opportunity to increase its political and commercial influence in the world, the region, or even the localities. They try to influence opinion towards the particularities of a politically and economically freer world. Existing legislation shows that if countries were to agree on signing bilateral trade agreements, or were to adopt the perspective to negotiate other multilateral regional agreements in terms similar to the ones signed with Chile and Singapore, they would have to make substantial changes in the political and economic structure to govern large investment and trade flows. The bilateral talks agreed upon were the result of ten years of negotiations, where countries' industries had to come to terms on many commercial considerations.

Hemispheric consequences of the first two signed bilateral agreements, which represented the biggest U.S. free trade deal since the North American Free Trade Agreement signed ten years ago, suggest that other bilateral trade and investment agreements will be extended to other regional countries, affecting their multilateral regional agreements. Chile's and Singapore's agreements for example, achieved the negotiating objectives set by the Trade Promotion Authority-TPA, making out of them an arrangement where a substantial benefit resulted for American interests in agriculture, industry, services, consumers, small businesspeople, labor, and the environment, with good governance. ${ }^{1}$

On specific trade subject's market access, all tariffs and quotas on all goods will be eliminated after twelve years of increased bilateral trade. Under the Chilean agreement, $85 \%$ of bilateral trade and consumer and industrial products becomes duty free immediately, with most remaining tariffs being eliminated within four years (Umaña, 2003, et all.). The investment section provides strong protections for U.S. investors, while also making improvements to the NAFTA Chapter 11 model called for in the TPA by providing for more transparency, and for public input in disputes and mechanisms to improve the state investor process by eliminating claims. On intellectual property rights and enforcement, they agreed on provisions that go beyond the disciplines in the WTO agreement on trade-related aspects of intellectual property rights. The agreement

\footnotetext{
Hearing of the Trade Subcommittee of the House Ways and Means Committee, June 13, 2003. The U.S. Bilateral Free Trade Agreements With Chile And Singapore. Headline: Hearing of the Trade Subcommittee of the House Ways and Means Committee. Subject: Implementation of the U.S. Bilateral Free Trade Agreements with Chile and Singapore. Chaired By: Representative Philip M. Crane (R-Il). Location: 1100 Longworth House Office Building, Washington, D.C.
} 
set a standard of protection for trademarks, copyrights, patents and trade secrets and established a tough enforcement regime for piracy and counterfeiting. The labor and environmental provisions in the Chile and Singapore FTAs are of significant concern.

Gradually, as negotiated conditions unfold, there will be freer access to agricultural products and to services for consumers. As trade barriers disappear, the FTA is considered a convergent stepping stone towards the scenario of the FTAA and WTO talks, which include some other politically complex matters, and are determinants for new forms of trading. Specific products related to the production of cattle raisers and farmers in America will benefit from a Chilean open market, as most tariffs will be eliminated on an 8,10 and 12 year basis. Counterveiling duties and quota reserves were negotiated for some strategic products. Market support payments, bound rates to certain products, loan payments and commodity loan programs are not open to negotiation. Counterveiling duties in case of dumping will immediately apply if the case is proved following dispute settlement procedures. There are several other issues that arise and where a response from the USTR remains. The intellectual property provisions locked into the current state of U.S. law are making it difficult for Congress to change in the future. Nevertheless they are considered fundamental for widespread multinational investment abroad.

Price band rates and duties on imported products like wheat, wheat flour, edible vegetable oil and sugar are allowed in the WTO agriculture agreement. However, export subsidies will be allowed if the WTO gives notice and the subsidies are reduced over time. Duties higher than $31.5 \%$ will be reduced to eliminate the disadvantage U.S. exporters face from subregional agreements within the hemisphere. Preference programs generate disadvantages as subregional trade agreements have proliferated in the hemispheres as part of the reform process undertaken by the FTAA countries.

Export subsidies will be maintained for some time; however, they will be suppressed when harming US and Chilean production. Origin rules will follow NAFTA's bottom up methodology. Rules of origin will apply the NAFTA procedure to calculate the level of local content. Value test requirements refer to a certain percentage of the value added, which must come from the country's labor, parts, and production. The second origin test requirement is the tariff shift approach. This confers origin if the production process transforms a product and its inputs enough to classify it as a different product in the tariff schedule. Decisions based on a product-by-product basis and tariff shift approach are less complicated to administer than the value added.

Multilateral political and trade talks continue to advance, following different path dependent routes. This, after four Presidential Summits defended democracy and proclaimed the organization of trade according to free trade rules. From the present historical standpoint (and after the FTAA Ministers negotiated in Monterrey in 2003 and copresidents of the Trading Committee-CNC congregated in Puebla on February 6, 2004), we foresee that the multilateral negotiations will run parallel in some aspects to the bilateral talks. The copious negotiation exercises led to the signing of agreements with similar terms on 
market access, agriculture, services, foreign investment, public procurement, intellectual property rights, subsidies, antidumping practices, and controversy solutions etc. In addition, if the route of plurilateral talks is adopted where negotiating parties are involved, they will have to agree on matters related to best practices and civil society, and on involvement in the negotiation talks after the agreedupon G-14 countrie's strategies, they will have to decide on broadened FTAA matters like:

Investment policy.

Trade in services.

Controversy solutions.

Public procurement.

Colombia as well as other Andean Community countries signed a new free trade agreement with Mercosur, after eight years of negotiations, complementing other existing agreements like the G3 and the Andean Community Treaty. On the first of July 2004, the agreement text was to be published, but it is expected that for Colombia, about 12 percent of Colombia's exports to Argentina will gain immediate tariff-free access, including graphic industry goods, flowers, shrimp, asparagus and cocoa butter. A total of 58 percent will obtain this in eight years and 71 percent within 10 years. About 77 percent of Argentina's exports will gain tariff-free access to Colombia over 12 years. With Brazil, about 24 percent of Colombia's exports gain immediate tarifffree access, including coal, tires, medicines and flowers. A total of 88 percent will obtain this in six years and 97 percent within eight years. Brazilian goods will gain tariff-free access to Colombia over 12 years.

A leading sector will be the pharmaceutical area where Argentina has agreed to inspect
Colombian drug producers in order to grant them licenses necessary to export. Argentine and Brazilian automotive goods will gain tariff-free access to Colombia in 15 years. The current Andean Price Band system will only be dismantled in 15 years, to give Colombian agriculture time to adjust to freer trade. Tariffs on trade in sugar and sugarderived goods will only be dismantled "once the signatory countries consider conditions are convenient". The agreement's signatories promise to apply only phytosanitary rules, according to World Trade Organization standards for protection of animal and human health. They will also move to harmonize these rules. To qualify for tariff benefits in Mercosur, Colombian goods must have at least 50 percent regional content in the first seven years of the agreement and 55 percent as of the eighth year. Mercosur goods must have 60 percent regional content (Miles K. Light, 2003).

\section{Past and Present of Hemispheric Trade Negotiation Talks}

Historical determinants after two centuries of globalizing events in the world suggest that countries ${ }^{2}$ space is no longer separated by distance and by historical time due to a lack of complementary economic and trading practices. What we see from a careful examination of the immediate historical past is that the world gradually melts into a new but largerworld-system. ${ }^{2}$ Political structures

See the work of Geoffrey Parker (1998: 147). He expresses conclusions about a holistic approach to international relations advocated for linking economic, political and geographical factors together, reminding us that maritime powers made global connections. 
conceived around a world-system explain much better why countries mutually integrate into an interconnected and interdependent worldwide configuration, although in the meantime trading arrangements of a most diverse nature are considered everywhere to regulate and link countries as pieces of a global market (Cfr. Hinsley, 1967; Walters, 1995; Wallerstein, 1974 y 1980, and ChaseDunn and Grimes, 1995). Specialized literature on international relations shows other variants of globalization; for example, issues about the repercussion of trading practices as world power is distributed. It is in this kind of international relations venue where unilateral, bilateral and multilateral agreements are used as tools to determine a stable distribution of a portion of world power and to facilitate the conciliation of commercial interests.

As we suggested in the first section of this paper, the diplomatic relations with the United States and with some other hemispheric nations are gradually evolving toward the liberation of enormous wealth as we advance toward the integration of a larger "building block system" of trade. Some unilateral decisions like the Andean Trade Preference Act now denominated ATP-DEA, which encourages trade by exporting more than 6,000 items to the United States free of export tariffs, provided that these countries exercise drug enforcement action to prevent drug trafficking from continuing under the surveillance of Plan Colombia. Other bilateral accords like the Trade and Investment Commission-TIC, subscribed to by the United States and Colombia, regulates bilateral trade. Some formal bilateral trade agreements subscribed to with the United States, under the auspices of the Trade Pre- ference Authority-TPA, ended in a long-term experiment for freer trade after attempting the negotiation on several occasions of a Bilateral Investment Treaty-BIT, and successfully fighting a war against drugs. Theoretical developments in multilateral trade talks will end in a political commitment to integrate the Americas, making of them an ambitious experiment, related to which the hemispheric presidents reached agreement on democracy and free trade in Miami in 1994, as suggested by copious amounts of specialized literature. ${ }^{3}$

\subsection{The Emerging Global Factors}

The historical connection between past and present furthered the advancement of the very ambitious project of the Summit of the Americas. The agreement is considered as a new definition of international relations, and perhaps as a customized view of the $19^{\text {th }}$ century Monroe Doctrine, in that it proclaims the interest of the US to globalize its interests in different areas of the hemisphere, this structure being a mixture of political practice and a basis to sustain economic growth. This matter is still not well understood by policy makers in many countries. It is along these lines of inquiry that we must observe how historical events are framed and deepened, according to three major elements or currents that account for this historical response as a step to a future of trade development. Glo-

Refer to the works of Blanco and Zabludovsky (2003); Rocha, Perilla y López (2003); Umaña, et al. (2003); Anzola Gil, Caballero Sierra y Corral Strassmann (2002); Cano (2003), y United States General Accounting Office, Free Trade Area of the Americas-Negotiators Move Toward Agreement That Will Have Benefits, Costs to U.S. Economy. GAO-01-1027. Washington. 
balization as a world historical force is regarded as a geopolitical phenomenon that first becomes an element that relates to modernization and to the development and diffusion of global capitalism. In economic terms, it has repercussions on the structure of the agreements in the field of world production, affecting trade relations, distribution and consumption of goods. In the political realm, it underlines the way that power is distributed among the different agents, establishing new conditions for negotiation in the management of decisions. In the cultural aspect, its impact seems universal because the structure of established production needs an open atmosphere. In a new social contract, symbols, beliefs, preferences, and socially differentiated values will have to be similar to a "Pax-Romana".

The emerging geopolitical outlook shows that a particular country's view is affected more and more by the commitments that gradually establish the condition from which the management of its political and economic variables evolves. This mirrors a second factor that means that the management of the International Diplomatic Agenda of each country is more and more complex to understand and exercise, and therefore determines the evolving framework for negotiation. One reason that explains why this complex environment must be analyzed from the historical perspective is the growing degree of interdependence between countries and economic blocs.

This changing situation leads us to take into account the use of the theory of building blocks and regional integration as a third approach to understanding and linking globalization, politics and organized institutions around a world that anticipates free trade, and where some temporary rules or initial conditions determine the evolving trade environment. We consider here that with this theoretical view it is possible to level the playing field in the hemispheric economic integration game to see how political forces and commercial interests interact. When the Free Trade Area signatory countries are not being protected by a political economic agent like the external tariff or a set of specific rules, they drift into what Bhagwati criticized about a trading area. That is that countries may be submerged in a sub-optimal trade initiative, as this alternative leads to a wide diversion from trade rather than an environment that generates trade (Cfr. Bhagwati, 1997: 22).

\subsection{Evolving Historical Determinants for Integration}

Reasoning along these historical and theoretical lines about globalization, we observe from another intellectual perspective that emerging integration institutions are the result of particular developments within the hemisphere. An up-and-coming view of the hemisphere shows that it is being converted into a single political and economic space, since it is regarded nowadays as a system that came from a fragmented and divided map made up of a number of countries, and is changing into a group of nations built out of the need to strengthen the group's finances and its trade positions. As the past balance of payments crisis, circumstances of high tariff practice, and imposition of quotas and trade barriers disappear, countries will enter into a new political and economic space. The general historical 
tendency is that we are seeing a hemisphere run by the liberalization of markets and by an opening and increasing space where opportunities emerge to allow the building of integrated markets around a single, larger and more complete playing field.

In this historical map of events that require a deeper scrutiny by statesmen, the first element that needed regulation to attain a worldsystem structure, at least in the Americas, was liberating capital transactions. Capital and currency movements were stringent and exchange rates did not respond to market forces, while multiple exchange rates distorted the price of international tradable goods. The 1947 Bretton Woods Agreement revealed how fragmented the globe was. The private direct investment process trend that followed the War became an important source of technological change in many countries, including developing Latin American countries. The expansion of capital markets and of low and diversified portfolio risk activities contributed to the increase of business mergers and of the acquisition of profitable firms, leading to substantial restructuring processes which have been well studied by an increasing number of analysts (Cfr. Huntington, 1996: 29 y 43). ${ }^{4}$

An emerging second historical element of importance that encourages integration is agreeing on trade matters within an emerging world-system characterized by a lack

4 Some of the leading authors in this emerging field are: Axford (1996), Ash and Trhift (1995), Bretherton and Ponton (1996), Dussel Peters (1997), Thomas (1999), Holton (1998), Lewis and Lewis (1992), Michie and Grieve (1995), Musbach (1997), and Parker (1998). of regulation of technological change, which in turn is caused by increasing manufacturing specialization and the emerging role of multinationals. Of critical need was an agreed-upon regulation pattern around multilateral negotiations on trade access and foreign investment rules. The third road to the creation of a building block scenario was the evolving historical idea of Panamericanism, a conception that embodied participatory government and the adoption in the hemisphere of Truman's Four Point goals, which were conceived to encourage longterm economic development as a condition for sustainable democratic rule.

After Panamericanism, in the 1960's, Kennedy, the father of the Alliance for Progress, delved more deeply into the concept of democracy that he tied to international aid as a fourth approach to mitigate inherited poverty, increasing people's political participation and accelerating development through land reform. Growth and social improvement were regarded as significant elements to support representative government at a time when the Cold War atmosphere was somewhat asphyxiating. During Kennedy's term, there was great concern over the advance of communism. Therefore, the A.I.D's Alliance for Progress carried out land distribution programs and plans to strengthen the economy through productive investment, thinking that it could thereby guarantee a more favorable political climate in the western hemisphere to protect nations against subversion.

The decade of the 90's brought a fifth historical landmark, particularly associated with the end of the Cold War, in which liberal views on democracy and trade stimulated a new 
way of applying and negotiating constitutions in order to rule hemispheric business. The economic growth cycle, the advance of hemispheric integration and a revival of democracy were general circumstances that encouraged thirty-four nations on the continent to pronounce an ambitious declaration of universal goals (Devlin, 2001). To add a new element to the theoretical effort to link democracy to development, Samuel Huntington (1996) in an interesting article, "The West: Unique, not Universal", suggested that integrating countries together along with modernization practices would evolve into making an objective of establishing this as a worldsystem.

\subsection{Achieving a Sustainable Democracy}

O'Donnell in his work on Another Institutionalization (1996: 7) indicated that the way to the modernization of the state involves a degree of surrender, because it includes the difficulty of preserving democracy. Attaining and preserving democracy is very important and sometimes painful because it implies the conceiving of institutional and controlling mechanisms that will allow the election of public authorities. Freedom of expression and information are the benchmarks of the creation of an active hemispheric infrastructure, in which governmental cooperation with civil society is active and complementary.

Principles such as the dissemination of international justice and moral conduct in international relations are essentials to a modern conception of democracy, especially if we support the thesis of having a hemispheric trade area in a region where democratic practices were preceded by years of "Caudillismo, Populismo and Caciquismo", as well as condemned dictatorial practices.

Rawls's (1975) ideas on international relations are included as well in the new discussion of supporting a view of democracy with a wider geographical perspective, especially if we attempt to satisfy the needs of poorer countries. These principles require conciliating equality, the right to selfdetermination, and the right to self-defense. Other authors, including Held, ${ }^{5}$ point out the complexity of the topic of sustaining democracy, especially within a global context, after showing that there are notable fractures in the process when various nation-states are involved or intertwined. His thinking has characterized international law, individuals, governments and non-governmental organizations as fractures that are subject to new regulations. He sees fractures between the theory of the sovereign state and the global system coming from the large number of international regimes and organizations. As globalization and hemispheric agreements affect national identity, other trends of fractures occur between the authority of the nation-state and the global or hemispheric system, including the realm of production, distribution and exchange on a wider scale. Francis Fukuyama (1991) in The End of History and Samuel Huntington (1996) in The Clash of Civilizations and the Remaking of World

See the book writen by David Held (1995), where some ideas are put forward to discuss democracy fractures. 
Order offer another interesting intellectual insight to illustrate to us, by means of a liberal view, how the world of today emerges or is made up of diverse, freely integrating blocs of nations.

\subsection{Deepening Colombian-US Relations}

Integration of Colombia into a more significant political and market space within the hemisphere is a process that has deep historical roots upon which theory may shed some light. It is a process that involved global, historical and political factors, as shown by Parks (1970), as he explains the long-term development of international relations where political and economic forces determine nations' economic advancement in his book Colombia and the United States 1765-1934. Randall (1992) also explains in Aliados y Distantes, that the dominating power in the world, exercised direct influence on the life of this country during different stages, and shows many relevant aspects related to foreign investment, oil industry and economic cooperation. In the area of bilateral relations, these relations evolved according to the diplomatic good neighbor procedure. Other important and contemporary aspects related to stabilizing democracy, and critical social issues like " $L a$ Violencia", determined the degree of involvement in the bilateral agenda as the Alliance for Progress implied a political and assistance effort to develop some programs advanced during the sixties and seventies to improve social conditions. Issues considered in the modern terminology of I.R. were the question of drugs, their production and distribution, an illegal business that developed during the nineties, the appearance of social tension and the still lingering spells of terrorism in Colombia and in other neighboring countries.

To advance the security and drugs fight, the US followed a criteria of general trade preferences extended to some Andean countries. The United States, which at one time offered the Caribbean countries an initiative known as the C.B.I. (whose determination was inspired more by political than by commercial terms), gradually allowed this policy to evolve into the unilateral view later enacted into the Law on Andean Tariff Preferences, known as the A.T.P.A. (now A.T.P.D.E.A). It was converted into a convenient interpretation of an ambitious commercial customs exemption granted to our countries and subject to the fact that the signatory countries fight coca and other drug plantations and attempt to curtail terrorism. A particular interpretation of this mechanism has been Plan Colombia, developed by Presidents Clinton and Bush to restrict drug cultivation and exchange this production for cash crops (Andean Trade Preference Act 1994 and TPA 2003 and Umaña, 2003).

The Bilateral Trade Issues discussed within the Commission on Investment and Trade, T.I.C, are prior steps to achieving more general proposals in commercial pursuits farther down the road. The T.I.C. became a meaningful element in the agenda sustained between Colombia and the United States, in which a complete review is done annually on commercial and investment matters affecting the two countries. This Commission studied trade problems concerning a set of products that have spe- 
cific control difficulties related to fulfillment of the existing regulations in the area of bilateral trade or rules agreed to in multilateral talks. As we advance into a bilateral Free Trade Agreement, changes and adjustments to the mentioned issues and policies will arise.

If we consider ambitious plans to integrate the Hemisphere into an area ruled by democracy and to expand trade practices to convert it into an engine of growth, we must refer to the final document of the Summit of the Americas, signed in 1991 in Miami by 34 democratically elected presidents. The political effort that concludes the transition from unilateral imposition into multilateral agreement is an anticipated response to globalization, where the foundation of a world-system has been a consequence of the development of capitalism, extending to many open market and liberal policies adopted by friendly countries. Trading rules are now governed by more multilaterally oriented approaches like the comparative advantage thesis, more liberal like the competitive approach to production, and more ethical as equitable distribution and gains are pursued. Based on this wider framework for making policies, countries implement many general rules oriented towards organizing free markets into a venue where goods and services move more freely around the world. The eruption of new technology, as well as the mentioned set of initial conditions to frame financial exchanges, lead to the enlargement and acceleration of the endowed process of globalization, where countries of different size and importance concur.

\subsection{The Road toward the Summit of the Americas}

Before trade agreements are formalized within the FTAA framework, or terms are even arrived at within a bilateral trade agreement, structural changes would well be made to stabilize the economy or to achieve people's representation within democratic institutions. The wider historical view developed in this review of the past observed from the present allows us to see how we have departed from a fragmented view of the world into a more general and coherent political and economic set-up, after the reforms adopted since the Washington Consensus in the late 80's. A political action plan followed to preserve and promote communities and democracy, stimulate prosperity through economic integration, eradication of poverty, civil society participation, respect for human rights, and sustainable development.

The Consensus to guarantee the reign of macroeconomic stability required deep reforms in areas such as: free trade, foreign exchange movements, free rates of interest, free mobilization of capital, labor and pension reform, freer policies to attract foreign capital, tax reform, and privatization of state firms.

The new, so to say, 1994 global Miami Summit project, inspired by profound institutional initiatives of Presidents Bush, Clinton and Bush Jr., groups together twenty-three policy programs, mostly of political content, and one that the FTAA conceived as an enormously important trade and investment plan to cover the whole hemisphere. 
After the 1998 Santiago Summit agreements, another eleven political and social initiatives were provided. These statements comprised an attempt to organize an order or new "World-System" to preserve democracy, deepen economic development, improve equality, eradicate poverty, provide facilities for education to a majority of citizens and encourage increases in hemispheric trade. In the area of trade, it was agreed to form nine working groups, among which the Agreement negotiated equality of conditions, with thirty-four countries participating in discussions on the future of the continent, exploring the topics of trade and investment.

\subsubsection{The Santiago Summit}

Analysts consider the 1998 IVth Ministerial Meeting held in San José a landmark of hemispheric integration. Relevant aspects of the process of integration held the FTAA to the conditions of its framing in a democratic setting, encouraging steady progress in the liberalization of hemispheric trade, highlighting the process of sub-regional integration, and other bilateral trade agreements under free trade principles. The negotiating rule of single undertaking became the general law for agreement and the guiding principle that lent transparency to the process and guaranteed application of the WTO clauses and commitments. The institutional atmosphere was encouraged by the formation of the Committee for Trade Negotiation-CTN, a body oriented to guide the work of the negotiating groups and to contribute to decisions on the agreement's structure, as well as negotiable topics.

The IInd Presidential Summit of the Americas held in Santiago in 1998 just after the
San José Ministerial Meeting, proposed to continue dialogue and strengthen hemispheric cooperation, reconfirming the urgency of strengthening democracy on the continent, as we said, along with political dialogue, economic stability, progress toward social justice, and of the need to agree on trade liberalization policies and hemispheric integration. Along general lines, it agreed that negotiations would commence on the main topics to be negotiated by the nine working groups, and that initial conditions would define (perhaps meaning the existence of) a space for "Path Dependence" growth.

The so-called initial conditions proclaimed by the FTAA, such as the following, highlight further implications for future development, particularly access to market agreements, customs procedures and rules of origin, investment, standards and technical barriers to trade, sanitary and phytosanitary measures, subsidies, anti-dumping rights and tax compensations, small economies, purchases by the public sector, intellectual property rights, competition policy and services.

A crucial point that had to do with the mechanics of negotiation was the formation of the Committee for Commercial Negotiations$\mathrm{CCN}$. Its function was to guide the work of the negotiating groups and to contribute to decisions on the structure of the agreement, as well as the institutional topics. Nine working groups were established with a President and Vice-President for each, which should reflect regional balance and avoid reelections, their having chosen Miami, then Panama and lastly Mexico City as seats.

The tri-partite Committee, ECLA, OAS and IDB, offered technical support for matters 
related to the negotiations and contributions from other multilateral, regional and subregional institutions that would be accepted. Public participation was considered a facilitating principle that lent transparency to the negotiation. Trade and production sectors, such as academic groups that are particularly active in this field, were welcome to befriend the FTAA. Equitable negotiation requires a high degree of responsibility and prior preparation on the part of the government and civil society. For the analysis before the signing of the Nafta treaty, Mexico and Canada formed a high level negotiating team (Robert, s. f.) ${ }^{6}$ in charge of exploring alternatives before beginning formal negotiations with the United States and Canada (ALCA, 1998a).

\subsubsection{Furthering the Agenda}

The Second 1998 Summit of the Americas proposed the continuation of dialogue and amplification of hemispheric cooperation. The urgent need to strengthen democracy on the continent, political dialogue, economic stability, and progress toward social justice, and to establish open trade and hemispheric integration policies was reconfirmed. The novelty of the meeting was a commitment to stimulate education as a factor in support of political, economic, social and cultural development. Science and technology were seen to play an important role in the preparation of educators. The topic of education for democracy was to be further studied, promoting actions that would lead governmental institutions to become participatory structures.

6 To understand different game theory principles, adopted to gain bargaining power in the productive sectors negotiation.
In general, the Santiago Summit commitments placed democracy within the framework of priorities as a very precious supranational goal. Arguments over correspondence between democracy and growth were complemented by discussions that linked democracy to free trade and investment as conditions for progress -conditions similar to $19^{\text {th }}$ century purposes for world trade. Along with these connecting arguments, other general objectives for preserving democracy are achieving a consensus as to liberal policies, maintaining harmony along with stability and efficiency, improving the quality of democracy, preserving the basic principles of liberty, justice, equality, representation and participation. Propitiating accountability in elections, increasing participation and representativeness, and guaranteeing equality of citizens before the law and respect for their individual rights were also agreed upon. Other topics such as guerrillas, drugs and violation of human rights implied an extension of the agenda, to include aspects related to security; thereby avoiding, and it must be dealt with Colombia's becoming another VietNam. The latent danger lies in the internationalization of the conflict, and it must be dealt with as a way to preserve democracy and protect trade. ${ }^{7}$

To reach these general goals, an ambitious and complex political action plan is needed that will be put into practice in each of the countries. This means that at the Summit, political guidelines were agreed upon to promote political and economic convergence. It was agreed that progress had to be made on other important fronts for the purpose of strengthening democracy through: Promoting human rights; community participation; promotion of culture and its values; struggle against corruption, drug trafficking and laundering of money; prevention of terrorism; free trade and support 


\subsubsection{Ministerial Meetings and the FTAA}

The process of forming a hemispheric free trade zone must finish its negotiation stage before the year 2005. Following the Miami Summit, many companies, workers, political parties, academic institutions and non-governmental organizations were summoned to cooperate with the national and regional efforts made to strengthen the links between governments and their societies. In June 1995, after the Denver Meeting, the existence of seven working groups was approved, together with their study topics and schedules, in order to identify the points for negotiation. In Belo Horizonte in May, 1997, the third Ministerial Meeting was held, and the Ministers of Trade approved the initiation of the FTAA negotiations for April, 1998 in Santiago de Chile during the Presidents' Summit. At the Preparatory Committee Meeting in October, 1997, the Vice Ministers analyzed the formation of the working groups and recommended that the objectives of the negotiation and its principles be discussed at the ministerial meeting. These discussions were the basis for the beginning of the San Jose Act, signed at the Fourth Meeting of Ministers of Foreign Trade in March, 1998.

for the World Trade Organization; support for convergence programs; development of capital markets; orientation of private credit to stimulate investment in physical infrastructure; development of telecommunications networks; cooperation in science and technology; access to education and health services; fostering of micro-enterprises; sustainable use of energy; and an alliance for biodiversity and prevention of contamination.
The ministerial proposal to continue negotiatin by blocs was accepted for the cases of the bilateral talks and even for negotiations with Mercosur, Can, Caricom or Central America, which supported, in principle, the GATT and its most favored nation clause and Article XXIV on negotiating with regional preference zones. Negotiations will take place up until 2005, when the FTAA will take effect (Hirst, 2001).

According to Wintraub (2004), in the Monterrey Summit the participants declared that the negotiations looking toward a Free Trade Area of the Americas (FTAA) were conceived and promoted to affirm that "the well-being of our people requires the achievement of three closely linked and interdependent objectives: economic growth with equity to reduce poverty, social development, and democratic governance." The section on economic growth deals with the need for external financing, promotion of micro, small, and medium-sized enterprises, international financial architectural reform, securing property rights, and reducing the cost of sending remittances. The governance section deals with the strengthening of democracy, the promotion of human rights, the need for transparency in government activities, and the intensification of efforts to root out corruption. The United States wanted the declaration to reaffirm the target date of December 31, 2004 for completing the negotiations for an FTAA, and the Brazilians opposed this, arguing that it would detract from the priority of this summit on social issues. Controversy also arose on corruption and whether corrupt governments should be excluded from future summits. Another controversial item was a proposal to work to reduce the cost of sending remittances 
by at least 50 percent by 2008 . A bilateral issue worthy of note was the speech by Carlos Mesa, president of Bolivia, in which he called for President Ricardo Lagos of Chile to give Bolivia "free, useful and sovereign access" to the Pacific Ocean. An examination of the economic and social aspects of that document makes it clear that the aspirations can be met over time only if there is consistent economic growth, as poverty cannot be reduced without this development (Cfr. Weintraub, 2004).

\subsubsection{Working Groups on the FTAA}

The core of the FTAA negotiations on the access and regulatory aspects of trade developed in nine categories. In addition, at the time of writing this paper, after the $17^{\text {th }} \mathrm{CNC}$ Presidents meeting held in Monterrey on February 6, 2004, countries agreed that they will advance negotiation on a multilateral ba- sis on all commitments in the nine negotiation groups. A plurilateral G-14 that invites countries to participate in a less ambitious multilateral negotiation was framed concerning the Investment, Services, Dispute settlement and Government Procurement.

However, since the San Jose Ministerial talks, negotiation groups developed rules and institutional provisions and took steps to address crosscutting themes. Five negotiation groups were established to develop schedules for reducing tariff, non-tariff and other barriers to trade and to draft a chapter outlining associated trade rules. Other groups developed rules on intellectual property rights, subsidies, antidumping, countervailing duties, dispute settlement and competition policy. After the issuance of the third draft in 2004, most groups are in heavily bracketed text denoting that they are still in dispute. Some of the most significant elements of this agreement follow.

Table 1

FTAA-Negotiation Groups

\begin{tabular}{|l|l|l|}
\hline \multicolumn{1}{|c|}{ A. Market Access Groups } & B. Institutional Provision Groups & \multicolumn{1}{c|}{ C. Crosscutting Themes } \\
\hline Market Access & Intellectual Property Rights & Smaller Economies \\
\hline Agriculture & $\begin{array}{l}\text { Subsidies, Antidumping and } \\
\text { Countervailing Duties }\end{array}$ & Electronic Commerce \\
\hline Services & Dispute Settlement & Civil Society \\
\hline Investment & Competition Policy & \\
\hline Government Procurement & & \\
\hline
\end{tabular}

Source: Based on United States General Accounting Office. Free Trade Area of the Americas-Negotiators Move Toward Agreement That Will Have Benefits, Costs to U.S. Economy. GAO-01-1027. Washington.

\subsubsection{Market Access Group}

Access to Markets. On this topic, the work of information gathering on tariff and non-tariff barriers and preferential access conditions was a primary objective, as intraregional trade represented US\$650 billion in 1999 for intraregional trade in industrial products. The group reached an inventory of the customs classifications, including phyto and zoo-sanitary measures, as well as the health measures that were applied by countries in the hemisphere. 
Likewise, this information allowed understanding of the barriers and technical standards on trade, especially tariff and non-tariff measures, rules of origin, safeguards, customs procedures, and technical barriers to trade. Although it is expected that coordination of this type of instrument has been studied in the respective technical groups, the information was registered according to the customs sub-classifications on how the goods will finally be registered upon entering the countries. The definitions with respect to the tax reduction program, inasmuch as initial tariffs and coverage of the program are concerned, will be given once the treatment to be granted small economies is clear.

There is a consensus that the FTAA must be established based on WTO norms, promoting the expansion of existing trade blocs. Based on the foregoing, the following consensual recommendations recognized the importance of linking these topics with others such as: non-tariff barriers, technical standards, sanitary and phytosanitary regulations, subsidies, etc.

Equilibrium in the negotiations on access to markets requires consideration of aspects such as services, infrastructure, investment, intellectual property rights, solution of differences, competition policies and others. A process of preparation and strengthening of micro and small enterprises was contemplated in order to develop an adequate level of competition. The liberalization of the agricultural and livestock sector has been a matter of controversy, mainly due to American subsidies and grants to producers.

A group set up on textiles and garments attempted to ensure prevalence of hemispheric preferences. A timetable and the manner in which to incorporate special customs regulations like free trade zones and export-processing zones in the hemispheric integration process were analyzed. The group agreed upon the liberation of trade in the field of entertainment, including films, videos, TV programs, production and distribution of entertainment business products.

Developed countries offer better access to their markets, speeding up the elimination of protectionist customs tariffs on clothing, sugar and leather and at the same time allowing longer periods for tariff reduction in the small economies. Ensuring compliance with and monitoring of agreements and obligations, a goal that was reached. Divergence on this topic existed on whether there should be simultaneous and immediate global negotiation, and the need to undertake negotiations on a gradual basis. Some recommended individual negotiation for each country and others emphasized the need to proceed by means of the existing sub-regional agreements. The 113-page text draft includes a range of proposals similar to WTO multilateral disciplines.

FTAA countries agreed on the base rate or starting point from which tariffs will be reduced, which has to do with the pace of tariff elimination. A basket will eliminate tariffs immediately, in five years, or in 10 years for the most sensitive cases. A decision will be adopted on which years of trade data will be used to calculate each country's concessions on a trade-weighted basis.

- Customs Procedures and Origin Regulations. The negotiation group proposed a progressive elimination of tariffs and 
non-tariff barriers. The work being done in this access group in an attempt to synchronize and simplify customs procedures is important, as is the search for a transparent scheme to establish origin and an agile administration. However, the most important factor to achieve these objectives has been the technical cooperation in the customs area, and in the analysis of the possibility that the rule on origin be studied together with the tax reduction program. With respect to principles, compatibility with GATT Article 21 is sought, aiming to preserve the coexistence of bilateral and sub-regional agreements, as well as pursuing gradualism, equilibrium and simultaneity in partial agreements. A proposal to determine whether a product qualifies for tariff preferences requires that for a certain product to be considered from the FTAA region, at least 60 percent of its value must come from an FTAA country's labor, parts and production. Rules of origin are intended to ensure that benefits of a trade agreement primarily accrue to the countries covered by the agreement. Agreement on origin requirement is a value test based on the percentage of value-added in a country, or the approximation of the tariff shift. In the Business Forum, there has been discussion on the construction of a symmetrical customs system and of unifying criteria on origin standards for goods and services.

Safeguard measures crafted a mechanism to provide the FTAA countries with temporary assistance to industries seriously injured by increased regional competition, and are temporary mea- sures that freeze or roll back trade liberalization, providing the industry with time to adjust to increased competition. An important challenge to negotiations is Customs Procedures, as countries lack experience in this subject, as there is not sufficient institutional capacity for implementing customs procedures necessary to enforce laws and proposals and conduct with transparency, efficiency, integrity and responsible customs principles. Technical barriers to trade are significant to exporters because, despite tariff elimination, products may be denied access if they fail to meet technical requirements on aspects such as human health, safety and environmental reasons. Ministers have been working on compiling tariff and nontariff measures, negotiating a safeguard regime, deciding modalities for negotiating the tariff schedules and rules of origin.

Agriculture. Sanitary and Phytosanitary Measures. Agriculture is one of the most debated issues in the FTAA negotiations. US agriculture exports to the hemisphere could expand by more than US\$ 1.5 billion annually, increasing income for almost every FTAA country as demonstrated by Mexico in the NAFTA. The US would like to increase access to South American grain markets, but maintains high tariffs on sugar and orange juice and provides farmers with support payments on a number of products. Other countries maintain a price band system designed to insulate domestic markets from international price fluctuations. The agriculture group is working to eliminate tariffs and nontariff barriers. With regards to sanitary and 
phytosanitary measures, the job of compiling regulations is fundamental to the synchronization of the various liberalization schemes provided for, not only in national legislation, but also in regional agreements. The ideal for the progress of this group is to eliminate agricultural export subsidies, identify other trade-distorting practices and implement the WTO Sanitary and Phytosanitary agreement.

Controversial issues within the agriculture group are domestic support programs, the reduction of which the US claims may be achieved in multilateral negotiations such as the WTO, and determining how to handle each country's sensitive sectors. Brazil is competitive in orange juice and sugar, two products for which the US maintains high tariffs. Ministers have not reached agreement on how to handle third-party export subsidies nor on what constitutes an export subsidy.

FTAA countries propose to suspend tariff preferences, and include in the term agriculture subsidy programs things such as export credits, credit guarantees, program insurance and food aid. Ministers instructed the group to:

Develop tariff modalities for negotiations. Identify non-tariff measures.

Introduce a methodology for eliminating export subsidies

Develop recommendations on the treatment of all practices that distort trade in agricultural products.

Services. The US is interested in this market for services to be relatively open, as it represented US\$253 billion in 1999. The services sector includes telecommunications, financial, professional, distribution and travel and tourism services. Liberalization of the services sector can foster greater competition and efficiency, and some countries have privatized previously state-owned service monopolies as part of their economic reform plans. The draft text includes proposals on topics that include safeguards, subsidy provisions, general exceptions to the rules and domestic regulations, including some reservations to the general rules. The agreement includes cross-border supply of services and the offering of a service by a company with a commercial presence in another country's market, establishing a commercial presence by investing, and a provision in the agreement for subnational levels of government, time for additional disciplines for sectors and special requirements for financial services. The approaches to scheduling services commitments are a top-down negative list approach and a bottom-up positive list approach. In a negative list, all service sectors are subject to the core rules and countries must indicate which sectors they would seek to exclude. The positive list approach works the opposite way, where a country specifies only the commitments it plans to make. The US advocates the negative list approach, arguing that it is ambitious but allows countries the flexibility to deal with domestic sensitivities.

The recommendations are almost consensual in determining that negotiations on this aspect must take in all types of services, seeking thereby to make the liberalization process transparent, as previously agreed upon. The following were consensually recommended: 
- Negotiations must heed the basic principle of inclusion of all types of services in accordance with WTO provisions.

- The agreement on the FTAA services must be GATS-PLUS; that is, it must promote greater liberalization than that already agreed to in the GATS of the WTO or regional agreements.

- Restrictions must be progressively eliminated, according to a previously agreed upon timetable, and thereafter must avoid the approval of exceptions.

- National treatment must establish equal treatment, incorporating the most favored nation principle and promoting competitive opportunities.

Investment. Progress recorded in this area of the hemisphere is the consequence of the liberalization process and structural reform of the economies that help advance formulas that favor investment. Countries are interested in the synchronization of legislation, the adoption of mechanisms that will lead to a fair and transparent legal framework to protect investment, and the adoption of schemes to resolve conflicts. Some forms of investment and the establishment or entry of investment remain controversial. Still, matters that the foreign investor finds important are that countries eliminate double taxation of his profits, and that the Preparatory Committee's objective be to avoid discrimination, and to preserve a fair and equitable treatment of countries.

The work group has highlighted the need to publish and facilitate access to treaties, agreements and existing legislation on invest- ment in the Americas. It has agreed that it will consider the possibility of technical assistance for the smallest economies, through existing institutions or programs, as well as inter-governmental cooperation among the countries of the hemisphere, in order to help them prepare themselves to assume their obligations in this area. The debate centers on the extent of the ability of investors to challenge government actions, such as contraverting FTAA disciplines, and the inclusion of labor and environmental provisions in the text. Only 8 of the 33 other FTAA participants have bilateral investment treaties with the United States, while others expect to enter the framework of the WTO disciplines that are found in the Trade-Related Investment Measures-TRIMS, which include commercial presence as a mode of supply. Participants incorporate standards of national treatment and most favored nation treatment, performance requirements, transfers, expropriations, compensation, transparency of laws and regulations.

Broad agreement among FTAA governments is due to more than 60 bilateral investment treaties by countries within the region and other FTAA subregional agreements. However, controversial topics still confine the negotiations and some details must be resolved, like the ability of investors to challenge government actions as contravening FTAA disciplines, and the inclusion of labor and environmental provisions in the agreement. Giving too much power to multinational corporations relative to governments and citizens raises controversy, and so do dispute settlements which challenge government noncompliance with the FTAA, or even agreement on expropriation practices like paying 
monetary damages. Inclusion of provisions on labor and the environment are a matter of controversy. A proposal was made after the Buenos Aires April, 2001 meeting, but it was placed in brackets. Some FTAA participants liberalized foreign investor's entry, while some are reluctant to guarantee a general right of establishment to foreign investors in the Agreement. Covering portfolio investment is another difficult issue as the term "broad asset-based" is not well defined and there is not a definition of transfer protections against systemic risk of capital movements and transfers. The US is expected to propose a topdown or negative list approach to coverage, where member countries include reservations in a negative list for any sector in which they decline to take commitments under a positive approach. Those involved in investment will coordinate negotiation with the FTAA on services, as some are provided through investment and others are provided through cross-border trade.

Government Procurement. Parameters will be set on the treatment to be given to an economy's size, and it's correspondence with the size of its state purchases market. Few countries in the hemisphere adhere to the WTO's purchases code, since governments do not agree with foreign competition. Given the lack of transparency and the existence of rules and practices that favor national enterprise over trade and the productivity of economies, the establishment of a regime of equal opportunity is sought for the companies in the FTAA countries with respect to supply of goods and services for government projects.

This group consensually recommends that:

- Transparency be guaranteed in government purchasing.
- Mechanisms be established for contesting and solving controversy.

- Incorporation of the FTAA topic be gradual, with periods of transition and asymmetrical treatment for small economies.

- Discriminatory treatment be eliminated, giving national and most-favored nation treatment to all suppliers in the hemisphere.

- Anti-bribery laws be adopted and applied.

- A database be created with legislation, rules and procedures for the public sector, as well as a registry of goods and services generally requisitioned by the governments of the region.

Government procurement is considered a business valued at approximately US\$250 billion. The adherence to the agreement is voluntary, as was addressed in the WTO. After the ministers negotiating group met in Buenos Aires, it focused on matters like the application of principles such as national treatment and most-favored nation, valuation contracts, procurement exceptions, publication of laws and rules governing processes, qualification of suppliers, processes for selecting and awarding contracts, and dispute settlement. Government procurement has been considered a nontariff barrier, due to the tendency to award contracts to national firms rather than to make decisions based on price and quality. Strong recommendations made by the United States include procedural provisions on topics such as publication of a timetable and tendering procedures. A new version of the draft text to the Trade Negotiation Committee-TNC was submitted by 2002 . 


\subsubsection{Institutional Provision Groups}

Intellectual Property Rights. The countries in the hemisphere did a diagnosis of the status of commitments in this area. It must be kept in mind that progress in this area is vital for the consolidation of foreign investment. The objectives of Costa Rica's Ministry propose an agreement of mutual understanding to reduce the distortions in hemispheric trade. In relation to principles, they identify those of national treatment and the most-favored nation clause, avoiding any decrease in the level of protection of the countries during the negotiations. Intellectual property is not protected in the hemisphere. Therefore the TNC revised national legislation, taking into account the objectives provided for in the ADPIC on effective protection, reduction of distortions and hindrances to international trade. Likewise, it was recommended that measures be adopted and implemented to:

- Guarantee compliance with outside legislation.

- Combat pirating and falsification.

- Reinforce the judicial and police systems to guarantee the application of rights in effect.

- Foster the establishment in each country of an industrial property office.

- Encourage member countries to adhere to the principal multilateral agreements dealing with intellectual property.

- Urge countries to ratify WIPO treaties on Copyrights and the Production and Reproduction of Sound Tracks.

- Promote prompt adoption among governments of the obligations and terms established in TRIPS and the World Intellectual Property Organization-WIPO.
The goal of this provision is to reward creativity and to establish an environment conducive to the broad sharing of ideas, including those that create a decisive competitive advantage in terms of high-tech, knowledge based industries, software ecommerce and biotechnology. Some of the topics go beyond the WTO and Nafta by addressing technologies, treaties and issues that have merged since agreements were concluded. Draft proposals include 15 topics like trademarks, copyrights, layout designs of integrated circuits, patents, protection of traditional knowledge and access to genetic resources, utility models, industrial design, undisclosed information, and non-competitive practices. The U.S. proposal on intellectual property rights goes beyond the obligations undertaken through the TRIPS agreement and ensures protection in digital environments dealing with music, programs and literary works provided by the Internet. Exclusion of items from patentability is a matter of divergence, and the United States is trying to narrow the categories of products or processes. Members retain the right to exclude plants, animals and biological processes from patentability and are prohibited from granting patents to plants, animals and biological processes. As for trademarks, the main concern still is the relationship between brands and geographical indicators.

Subsidies, Anti-dumping and Compensatory Rights. Advancement in the compilation of the status of national legislation and in the extent of countrie's commitments to the WTO, in addition to being useful, are conditions for advancement in negotiations. In particular, it is necessary to define whether 
commitments will go beyond the WTO in some aspects. The topic of treatment of internal support for production is a matter of vital importance to the private sector. Analysis of subsidies is detailed to guarantee competitive conditions that are suitable for the productive sectors. In the Preparatory Committee, the objectives were to eliminate subsidies, identify practices that distort trade, such as subsidies, and apply anti-dumping legislation and allowances. Inasmuch as principles were concerned, it was recommended that negotiations be transparent and consistent with WTO obligations and allow the coexistence of bilateral and sub-regional agreements in the hemisphere.

The various parties stated whether they wished to support the commitments acquired within the Uruguay negotiations on most aspects related to government help for trade and producers. The discussion emphasized the mechanisms for solution of controversies within the FTAA through the creation of its own instruments, independently of whether the WTO has provided for them. The following consensual recommendations were attained on these topics: Incorporation and compliance with WTO rules; anti-dumping and anti-subsidy measures considered within the context of perfecting trade practices and developing business as tools to guarantee the transparency of business and freedom of trade; adoption of a timetable of tariff reductions for agricultural products adjusted to the freeing of quotas; and reduction or elimination of subsidy policies according to the commitments already assumed by the WTO.

Proponents believe an anti-dumping regime is necessary to offset unfair trade practices, while opponents view it as a protectionist system that shelters noncompetitive firms or industries, penalizing domestic consumers. Afterwards, Buenos Aires drafted a text including provisions on topics such as the determination of dumping and injury, investigations and evidence, provisional measures, addressing and collecting duties, and dispute settlement. Still, there is agreement about its proposals' implications on approaches that maintain that the WTO lacks rules like thresholds for sales below cost, or providing for a public interest inquiry that could result in the imposition of reduced dumping or countervailing duties. The three topics that negotiators are addressing are the anti-dumping draft text, regulations on nonagricultural subsidies, and the relationship between trade and competition policy.

Dispute Settlement. This code is considered the linchpin for the effective operation of the FTAA agreement as a whole. The issues are how to handle compliance, whether to allow appeals, the extent of public access to the process, and jurisdiction in relation to other international agreements. Dispute settlement will deter countries from adopting measures that do not comply with the FTAA. This chapter on agreement is intended to establish a fair, transparent and effective mechanism to settle disputes and promote the use of arbitration to solve private trade controversies. Considerable work is required on issues like consultations and resorting to neutral bodies or panels, settlement to redress violations, and differences in level of development and private commercial arbitration. Compliance and appeals depend on the legal basis for panel rulings. However, Nafta's general dispute settlement process 
does not contain an appeals mechanism. Transparency is proposed to be achieved via open hearings, public access to documents and opportunities for persons and companies to be notified of the initiation of the FTAA. The group has three mandates: prepare a revised draft chapter for presentation to the TNC, submit it to the Technical Committee on Institutional Issues to implement dispute mechanisms, and consider whether a proposal for special dispute settlement is compatible with procedures developed for the FTAA.

\section{Competition Policy- Technical Regulations} and Barriers to Trade. The mandate this group received was to attempt to propitiate progress in the compilation of national regulations. The importance of this lies principally in the degree to which such technical regulations can become barriers to trade. For businesspersons, it is extremely important that progress be made with the use of internationally accepted criteria and the synchronization of regulations and their application promoted among the countries of the hemisphere. Additionally, it is necessary that customs agencies be technically linked to the authorities in charge of these matters from one country to another, since they are the ones to apply the rules when merchandise enters the country. The Preparatory Committee set the goal of preventing technical barriers in the hemisphere and preserving congruence with the WTO provisions. With respect to principles, the idea is not to create new barriers to trade. Some supranational institutions that deal with regional competition disputes are working well, like the Andean Community and Caricom.
The group working on competition policies seeks to establish a framework that will allow it to guarantee that the benefits of the FTAA liberalization process will not be undermined by anti-competitive business practices. The group recommends the preparation of a compilation of laws on compensatory rights and anti-dumping. Furthermore, it makes a distinction between subsidies on exports from the agricultural sector and practicing dumping. In the area of competition, it is important to establish the criteria on which private agents and state monopolies will acquire commitments. National legislation should be evaluated to create harmony among processes and the authorities that judge cases (Anzola Gil, et. all. 2002). The group received the mandate of establishing a judicial competition policy and institutional coverage at the national, subregional and regional levels. It has agreed on a mechanism to promote competition and guarantee the enforcement of regulations on free competition among countries. Progress has been made on how monopolies and state enterprises should be treated, what national and subregional institutions on competition policy should cover, and what kind of dispute settlement might be appropriate. The draft text contains a proposal on dispute settlement mechanisms and another that calls for the development of a Competition Policy Review Mechanism.

\subsubsection{Crosscutting Themes}

Three additional non-negotiating working groups were established. These groups are in charge of the fundamental areas for consolidation of the integration process and are a conduit for information but do not produce text on trade rules, as do negotiation 
groups. They include smaller economies, e-commerce and civil society. Many countries consider themselves small or developing. E-commerce is an emerging theme that intersects negotiations on market access and services. And civil society fosters public support for the FTAA.

\section{Smaller Economies and Civil Society.} Although this group has advanced in the technical analysis of treatment of small economies within regional agreements already signed, it agreed to include it in each specific aspect with the negotiation groups. The definition of treatment to be given the small economies was needed in order to determine the starting point for commitments on topics of such importance as market access and subsidies. The Preparatory Committee group disappeared, and the topic was incorporated within each of the other groups. After the Buenos Aires Ministerial Meeting, the TNC assisted the consultative groups to apply a treatment that takes into account differences in levels of development and sizes of economies. The civil society theme has been controversial, as public support for the FTAA has been solicited from business and other nongovernmental groups. They represent business, labor, the environment and other interests. It is said that public support for the outcome is an important factor in generating the political will to conclude an agreement and reach transparency to facilitate the constructive participation of different sectors of society. In the Buenos Aires Ministerial Meeting, 77 acceptable responses resulted from civil society groups, including the Internet publication of the text agreement draft.

\subsection{The Enlarging Political Agenda}

Toronto Ministerial Meeting. Some international relations events deserve a certain amount of reflection, in order to understand that the international agenda of the hemisphere has become more complex. In a statement on November 1999, at the Fifth Ministerial Trade Meeting held in Toronto, the parties to the meeting reaffirmed the favorable climate existing since the meeting in Miami and embraced the principles of "single undertaking" to fulfill the task of reaching an agreement by the year 2005. They supported the initiative of freeing trade more and supported the idea of strengthening integration through the sub-regional groups, bilateral agreements, and adoption of unilateral measures of liberalization. The idea of combating restrictions on trade that had been adopted based on unilateral criteria was applauded. They showed the conviction that the principles of the free market contributed to the economic recovery and growth and under these principles they would support the meeting in Seattle.

Likewise, they celebrated the fact that in spite of hemispheric contrasts and their particular problems, both trade and investment had continued to grow. Both the small countries and the large ones will show special consideration in the process. For the purpose of linking the entrepreneur to the process and attracting civil society, networks of friends of the integration process were created. This information has been shared integrally and publicized by the governments of each country. One practical point of intense interest is the fact that the TNC-Committee for Trade Negotiations has the 
necessary institutional elements to coordinate negotiations.

Likewise, they celebrated the progress made in the nine working groups, the consultative group for small economies, the Committee for Governmental Representatives for Participation in Civil Society, and the Electoral Committee of Experts on Electronic Trade.

Buenos Aires Ministerial Meeting. In the ministerial meeting in Argentina in April, 2001 , it was agreed that each one of the signatory parties would prepare a detailed revision of the points discussed in each one of the groups on the topic of the FTAA. It was said they would take into account the opinions of each one of the participants in each of the areas, facilitating the negotiation of the corresponding groups. Topics such as access to goods and services markets deserved attention in the discussion on ways and means, and were finally included in the individual reports and submitted to the TNC. The work groups and vice-presidencies rotated and agreed to make public the complete information about the state of the negotiations by publicizing the first draft of the negotiations.

The Third Ministerial Conference of the WTO in Seattle, and the WTO procedures followed in a search for free trade. With respect to the topic of priority related to future multilateral negotiations on agriculture, the ministers announced they would work toward an agreement for multilateral WTO negotiation, elimination of agricultural subsidies, compliance with commitments made at the Uruguay Talks, and greater discipline to avoid practices that distort trade, and to be able to reach an agreement on multilateral negotiations. It was confirmed or, rather, ratified that the FTAA process would be transparent only to the degree that society shows its willingness, interest and commitment to the topic. Meanwhile, the academic, labor and entrepreneurial communities have been absent from the process. The North American Business Forum has been very active, submitting recommendations and proposals.

Millennium Talks In Seattle. The lessons learned from the failed Millennium Talks begun in Seattle to expand and free up trade can be summarized by the reigning inequality in the world with respect to flows of foreign investment (Cfr. Moore, 2000). Singapore, to cite one example, receives more capital resources than all of Africa. The world's having to house one billion additional inhabitants within the next thirty years brings out makes a central point on the issue of how, in the midst of this disconcerting panorama, trade can help to mitigate the problems of underdevelopment. Services and agriculture are topics of vital importance on the international agenda and deserve much attention, in spite of the dissident voices, first in Seattle and later in Doha. It has been proclaimed that to improve access to markets in the advanced countries, the existence of subsidies and grants must be eliminated.

The central point of the emerging agenda is associated with ensuring that trade and exchange work to the benefit of the poorest sectors, as agreed upon in Copenhagen in 1995. The best example of the benefits of trade can be illustrated by the four countries affected by the Asian crisis: Korea, the Philippines, Malaysia and Singapore, which 
reported growth in their economies, thanks to the growth of their trade by more than $9 \%$ annually. The ridiculousness in Seattle of attacking globalization stems from the fact that globalization is not a choice, nor a theory, nor a conspiracy. It is part of the process of economic progress.

OAS Assembly. Canada, one of the countries most interested in promoting the topic of the FTAA, hosted the members of the tripartite committee of the OAS Assembly in June, 2000 in Windsor, Ontario. The Ministers of Foreign Relations discussed the topics related to human security, and all the leaders of America had their eyes on Colombia, with respect to hemispheric security and the preservation of democracy. The armed conflict and the soaring business of drugs endangered not only Colombia but also its neighbors.

In this meeting, the Minister of Foreign Relations of Canada, the Honorable Lloyd Axworthy, reminded participants how the topic of drugs "continues feeding corruption, distorting value systems, benefiting money launderers, and sustaining illegal arms traffic and supporting the guerrillas and paramilitary forces". ${ }^{8}$ This problem, if not controlled, will extend to unprotected members of society, children being the most touching example of these injustices. The addressing of hemispheric security is in response to the treatment agreed upon at the Summit of

See speech by his excellency the honorable Lloyd Axworthy, Canadian Minister of Foreign Affairs. Permanent Council of the Organization of American States- OAS. Washington, D.C., 11 February 2000 .
Santiago and included in the OAS mandate on hemispheric security.

Due to Colombia's limited success in the peace process, our conflict has become internationalized to the point that the topic of displaced persons has become an issue for the OAS. In general terms, it has to do with including all citizens within the benefits of democracy.

The Summit and the OAS Agenda planners have been attentive to this aspect, and have therefore anticipated the events, by including this social structure in the negotiation process. The topic of democracy (which is a very sensitive one for Colombians), and other participatory processes, was discussed at a specialized forum on the same date as the Assembly. The Canadian International Center for the Development of Human Rights and Democracy sponsored a conference on "Hemispheric Integration and Democracy in the Americas".

In the Eighth Ministerial Meeting celebrated in Miami in 2003, the Ministers instructed the Trade Negotiations Committee (TNC) to develop a common and balanced set of rights and obligations applicable to all countries. The negotiations on the common set of rights and obligations included provisions in the following negotiating areas: market access; agriculture; services; investment; government procurement; intellectual property; competition policy; subsidies, antidumping, and countervailing duties; and dispute settlement. "On a plurilateral basis, interested parties may choose to develop additional liberalization and disciplines. The TNC shall establish procedures for these negotiations that shall provide that: coun- 
tries negotiating additional obligations and benefits within the FTAA shall notify the CoChairs of their intention to do so before the outset of the negotiations. The results of the negotiations must be WTO compliant". ${ }^{9}$ In the Special Summit of the Americas conducted in Monterrey in January, 2004, heads of state and governments of the Americas agreed on taking "all necessary and feasible legal, regulatory, and institutional measures, by the next Summit of the Americas to be held in 2005, to simplify the procedures and significantly reduce the time and cost of establishing businesses in each country of the region". Recognizing that political pluralism and sound political parties are essential elements of democracy, they adopted the principle and purpose of security as the protection of human beings and agreed that the Government of Argentina confirmed its offer to host the Fourth Summit of the Americas in 2005. ${ }^{10}$

\section{A Bridge to the Future. The Andean Community Responds to the FTAA}

The Andean Community is considered strategic for advancing in the FTAA negotiations as well as with other trading blocs like Mercosur, or even extending negotiations with other larger trading markets like the European Community or the APEC. However,

9 Free Trade Area Of The Americas. Eighth Ministerial Meeting. Miami, Usa. November 20, 2003. Ministerial Declaration. http://www.ftaa-alca.org/ Ministerials/Miami/Miami_e.asp

10 Special Summit of the Americas. Monterrey, Mexico. January 13, 2004. Declaration of Nuevo León. http:/ /www.ftaa-alca.org/Summits/Monterrey/ NLeon_e.asp trade agreements are negotiated according to some unilateral, bilateral and multilateral rules and procedures, and the Andean Community countries, with the exception of Venezuela, that were favored to subscribe a unilateral Trade Act with the United States are following some other trading strategies. Under the umbrella of the TPA, the US government granted the Andean Trade Promotion and Drug Eradication Agreement ATPDA, yielding to the signatory countries more than 6,500 tariff exceptions on goods exported to the United States. After Congress voted on the Trade Preference Authority-TPA or the 2002 Trade Law, the United States initiated a strategy to reach free trade agreements with different countries and granted the initiative to subscribe to bilateral trade agrements with Chile and Singapore, and regional agreements with the Andean Community countries. They also encouraged negotiations at a multilateral level following the WTO rules, which are sorting out the trade problems countries face with each other, especially under the "Doha Development Agenda" launched in 2001 within the world market.

A regional bilateral bloc view to create a hemispheric trade area and to take advantage of the TPA provisions was observed by Jeffrey J. Schott, who expresses a longterm view about a large free trade area in the Americas in his work Prospects for Free Trade in the Americas (2001). This author suggests that trade arrangements and other common macroeconomic balance of payments agreements and portfolio investments across frontiers reduce the effects of systemic risk on the external sector crisis, allowing for a long-term growth process in the world's largest market. 
Academic considerations as such moved rulers in the Presidential Summit in Quebec to launch a new political guideline to initiate a bloc-to-bloc negotiation scheme within the FTAA. The FTAA Quito Ministerial Meeting, conducted in November, 2002 , established the alternative to take advantage of bloc-to-bloc bilateral negotiations under the authority of the Trade Promotion Authority-TPA.

Enlarging the negotiation within the FTAA means trading within a market composed of 800 million consumers, valued at US\$ 11 trillion and a trade currently valued at US\$ 3.4 trillion. Between 1987 and 1999 intraregional trade increased $250 \%$, and in 1999 , trade within the Andean Region represented nearly $20 \%$ of total value and the US was responsible for nearly $66 \%$ of total exports. Foreign direct investment increased within the Andean region from US\$ 64.7 billion in 1990 to US\$391 billion in 1999. Since 1994, thanks to Decision 370, the Andean Countries adopted the mandate of transforming themselves into a regional common market, the common external tariff being $20 \%$. In October, 2002, 68\% of the tariff nomenclature adopted three category levels (Gil, 2001). Within the adopted field-leveling conditions to accomplish the negotiation proposal, some countries suggested a differential treatment to favor less developed Andean countries. These circumstances favorable to trade allowed bilateral negotiations to advance within the FTAA according to an established schedule, which we will review. ${ }^{11}$

Table 2

FTAA - Negotiation Groups

\begin{tabular}{|l|l|l|}
\hline A. Market Access Groups & B. Institutional Provision Groups & C. Cross Cutting Themes \\
\hline Market Access & Intellectual Property Rights & Smaller Economies \\
\hline Agriculture & $\begin{array}{l}\text { Subsidies, Anti-dumping and } \\
\text { Countervailing Duties }\end{array}$ & Electronic Commerce \\
\hline Services & Dispute Settlement & Civil Society \\
\hline Investment & Competition Policy & \\
\hline Government Procurement & & \\
\hline
\end{tabular}

Source: Based on United States General Accounting Office. Free Trade Area of the Americas-Negotiators Move Toward Agreement That Will Have Benefits, Costs to U.S. Economy. GAO-01-1027. Washington.

\subsection{Market Access}

Market Access and Agriculture started negotiations in May, 2002, and initially agreed on $68 \%$ of existing tariffs, nontariff barriers and subsidies, as well as other practices that distort trade. Progressively they will eliminate tariffs on agricultural goods, eliminate export subsidies, address other trade distorting prac- tices and sanitary and phytosanitary measures. Related to bound tariffs are the maximum duties that a country has committed to in the WTO to apply on some goods that

11 A detailed review on this issue is titled "Comunidad Andina. Bases para la Presentación de Ofertas en los Grupos de Negociación del ALCA". SG/dt 192. 9 de diciembre de 2002. 2.23. 
relate to the common external tariff. The starting point for reducing tariffs or base rate is the crucial element of the discussion, especially on agricultural products, where some US goods are subject to state subsidies. The United States is proposing that the base rate, from which tariffs are phased out be the lower of either a product's most favored nation rate, applied in effect during the FTAA negotiations, or the WTO-bound rate at the end of the FTAA negotiating process, as suggested by the US General Accounting Office-GAO (2001: 30) and Cano (2003) sources that we extensively quote in this section.

\subsection{Agricultural Tariffs}

After 2002, all agricultural tariffs are subject to direct negotiation (considering that different trade liberalization timetables exist within the FTAA.) Reaching an agreement on rules of origin, customs procedures and technical barriers to trade involving agriculture would be addressed in the market access group. Controversy still exists on how to categorize and agree on products that are sensitive to each country, eliminate agricultural export subsidies, suppress domestic support programs, identify trade-distorting practices for agricultural products, and deal with sanitary and phytosanitary measures.

To reach a consolidated text either in the bilateral agreements or within the multilateral agreement, tariff reductions will be regulated. Reductions will be linear, and only some exceptions will be admitted. The parties accepted four schedules for the reduction of agricultural tariffs (Cano, 2003). Some will have immediate effect, others no more than five or ten years, and very few will be granted longer terms. ${ }^{12}$ Services, investment, and government procurement presented revised proposals after July, 2003. Rules of Origin adopted the minimalist system and rules will be negotiated on a product-byproduct schedule. At least $60 \%$ of each product's value must come from AC or FTAA countries where labor, parts, and production represent a fraction of the value added.

\subsection{Market of Services}

The Andean Community had already regulated the market of services within the region, following Decision 439 and Decision 291 on investment, in prompt response to the WTO services agreement, especially GATT Article XXIV and GATT's Article V, to cover a cross-border supply of services, and the supply of a service by a company with a commercial presence in another country's market. The negotiation includes the ways in which a services provision in the agreement applies to subnational levels of government and the timing for developing additional disciplines for sectors, such as the telecommunications or the financial sectors. To approach the scheduling of services commitments, a top-down approach or negative list, as in the Nafta, is preferred, where all service sectors are subject to core rules, and countries must then indicate which sectors or measures they would seek to exclude from coverage. In the positive list approach followed in the WTO, a country specifies the commitments it plans to make. If the sector is not included in the

12 See the documents FTAA.TNC/1 8, FTAA.ngma/ 03/Rev.1/Add.1. and FTAA.ngag/05/Addl ./Rev.1. 
schedule, it is not covered by the agreement. In general, in the FTAA negotiations business representatives split over whether the FTAA should use a positive or negative approach.

\subsection{Investment}

Negotiations have yielded broad agreement on the thrust of the types of investment protection, but the establishment or entry of investment remains controversial. Portfolio investment, both stocks and bonds, account for $60 \%$ of the $\$ 661$ billion invested in the FTAA. The debate centers on the ability of investors to challenge government actions and on contravening investment rulings and including labor and environmental provisions in the text. Convergence in the negotiation has been set on basic ground rules for entry and treatment of investment, and lowering the risk for the potential investor. It also has set standards of national treatment, and most favored nation treatment. Negotiators aim to go beyond the Agreement on Trade-Related Investment Measures-TRIMS, even mitigating standards of treatment for investors and establishing mechanisms for dispute resolution. An agreement was reached after incorporating comprehensive rights and obligations on investment, and a methodology was adopted to consider reservations and exceptions to obligations. An agreement was also reached on loss compensation, transfers, expropriation, and a mechanism for dispute settlement and transparency of laws. Broad agreement about investment disciplines was due to the more than 60 bilateral investment treaties by countries within the region. Negotiators are working on a legal framework to promote investment through the creation of a stable and predictable environment that protects the investor and his investment. Issues like a minimum or general standard of treatment are addressed in the draft chapter. The issue of competence led the AC to adopt Decision 285 to address some general FTAA negotiation issues.

\subsection{Government Procurement}

It is considered a potentially great market opening opportunity for participants. It is valued in the hemisphere at approximately $\$ 250$ billion, and as government procurement negotiations do not proceed from the commonly applied WTO agreement, the negotiation group on government procurement shares the mandate to expand access to the government procurement processes. This mandate does not necessarily imply identical systems for each country, while ensuring nondiscrimination and impartial and fair review for resolving procurement complaints and appeals by suppliers. The level of the parties' economic development is taken into consideration in the negotiations. Some exemptions were requested by the $\mathrm{AC}$ countries to protect national industry and sectors called sensitive. Small and mediumsized firms require special treatment for government procurement, including technical assistance to improve market competitiveness. Some other technical matters include the application of principles such as national treatment, most favored nation, special and differential treatment for smaller economies, the threshold and valuation of contracts, which includes procurement exceptions, specific procurement procedures and a review of appeal procedures including dispute settlement. The United States believes that for the participants to enjoy the 
concessions that will be negotiated, the agreement must include specific procedural provisions on topics such as publication timetables and tendering procedures as found in Nafta.

\subsection{Intellectual Property Rights}

The US shows a decisive competitive advantage in high technology, knowledgebased industries dependent on intellectual property. Developing countries like the AC want to bolster enforcement of existing rules to cover new technologies such as the Internet and biotechnology. Some other controversial issues are compulsory licensing, patenting of plants, animals, and biological processes.

The ADPIC agreement offers minimum protection for dispute settlement. The $\mathrm{AC}$ advanced on Decisions 486 and 351 in technology transfer and treatment of investment, as being consistent with nondiscriminatory treatment of the investment phase, and other issues like author's rights, patents, internet agreements and contracts, industrial design and plans, especially in the establishment of protection standards, observance and dispute settlement. ${ }^{13}$

\subsection{Subsidies, Antidumping, and Countervailing Duties}

Many countries in the western hemisphere employ these trade remedies to counter

13 Decision 486, contains norms about patents, industrial practices, trademarks on integrated circuits. Decision 351, orders Author's Rights. Decison 392 for Genetic Resources. Decisión 391 for the protection of vegetables and other phytosanitary rules. Decisión 486 is the accepted regimen on Industrial Property Rights. subsidized or unfairly traded imports. The US proposed that countries be able to maintain their current antidumping and countervailing duty laws as permitted under the WTO clauses. Safeguard Measures are considered temporary, as their purpose is to freeze or roll back trade liberalization when it is shown that liberalization has caused injury to a domestic industry. These measures intend to provide the industry with time to adjust to increased competition. Regarding agricultural proposals, the degree of injury or impact to the domestic industry and the length of time the measure can stay in place, is definitive. The WTO safeguard measure determined that tariffs or quotas can be used for up to 4 years.

\subsection{Dispute Settlements}

Members are required to balance a desire for a strong regional enforcement mechanism against national concerns about sovereignty. Dispute settlement is recognized as a linchpin for the effective operation of the hemispheric agreement. The most controversial issues are how to handle compliance, whether to allow appeals, (allowing) public access to the process and resolving issues such as the FTAA's jurisdiction versus other international agreements like third party rights. The critical point of this topic derives from the rights secured and commitments made in the FTAA even if negotiations go beyond the WTO, thereby reducing the number of countries who adopt measures that do not comply with the FTAA, bolstering members' confidence by preserving the benefits balance attained in negotiations, and ensuring that recourse exists effectively and impartially to redress the countries (GAO, 2001: 69). Ecuador claims 
that paying attention to issues related to the degree of a country's underdevelopment involves offering longer-term periods to comply with the agreement's duties and extending judicial assistance to countries.

\subsection{Competition Policy}

Only 12 of 34 participating countries currently have competition policy laws; however, all agree that they should implement measures that proscribe anticompetitive business conduct such as monopolistic behavior. With regards to standards and Technical Barriers to Trade, a draft was submitted in November, 2000 for discussion, establishing a schedule to preserve the rights of countries to apply restrictions on imports for human health, safety or environmental reasons, while establishing procedures for avoiding measures that discriminate unnecessarily against imports. Still, countries may decide that additional rules are useful for expanding existing WTO commitments. Negotiators are working on the inventory of nontariff measures, along with a methodology to remove them. Some aspects with which parties to the FTAA and AC countries are coming to terms ${ }^{14}$ are the following: First, those referred to as Competition Policy, where each signatory country should implement measures to proscribe anticompetitive business conduct but disagrees over the level of detail needed in the agreement. This new legal area consists of the rules and regulations that foster a competitive environment in a national economy. This is attained partly through more efficient allocation of resources. Practices like

14 About convergence of opinions see SalazarXirinachs y Robert (2001). the ISO are commonly accepted, as well as competition policy laws, antitrust laws, and laws against fixing prices and misuse of market power by monopolies. Colombia and Venezuela currently have competition policy laws, while the Andean Community has supranational institutions to deal with regional competition disputes. AC countries advanced in setting the detailed anticompetitive code, like Decisions 419 and 376 about normalization practices and accreditation of academic titles. A peer review of competition policy laws and their implementation in lieu of binding dispute resolutions has caused fears that their implementation could serve as the overseeing body. Many of the competition chapter brackets should be easy to eliminate during the negotiation phase.

\subsection{Smaller Economies}

Smaller economies, which are characterized by a high degree of trade openness, a lack of economic diversity and a dependence on trade taxes for government revenues and on relatively small firms, have requested special and differentiated treatment. The 7th FTAA Ministerial Meeting in Quito agreed upon publishing the second FTAA Draft. ${ }^{15}$ Ministers approved a cooperation program and the differential treatment included special action according to different levels of economic development. ${ }^{16}$ Further negotiation talks were included in the agenda, one in Miami in 2003, another in Brazil in 2004 and the one in Puebla the same year. ${ }^{17}$ The $7^{\text {th }}$ Private Sector meeting gathered civilian views on the advance-

5 See http://www.ftaa-alca.org

16 See http://www.ftaa-alca.org/tnc18s.doc

17 See Anex II. http://www.ftaa-alca.org/tnc18s.doc 
ment of negotiations, as agreed on among the multilateral and plurilateral conditions to be followed after the 2004 Monterrey Ministerial meeting.

\section{Concluding Remarks}

Attempting to foresee developments on this very complex and interdependent integration of economies within the hemisphere with past historical developments that determined a path development process, we reach the conclusion that we are entering into a process of globalization that has historical roots and is somewhat deterministic, as suggested by authors like ForemanPeck (1995: 63) and others like Kenwood \& Lougheedd (1998), Rugman (2000), Scholte (2000), Schwartz (2000) and Shannon (1996). They proclaim, using different methodological currents, that we live in a world where historical determinants contribute to the rapid expansion of international trade and economic development something that we can hardly elude. The past occurrences connected with trade expansion had their origins in the advancement of the transportation revolution that linked the world into a single market, and in the creation of a modern banking system that links most economies to a single currency failing the gold standard, and to the spread of technology in world production. These and some other social and economic advances led the world to the construction of a global market governed by market rules. Events and man-made policies attempt to tame market forces and smooth the integration process of nations into this complex process that is revealed in this institutional picture.

\subsection{Emerging World Trade Scenarios}

Globalization is perhaps one of the main causes that encourages trading blocs to incorporate into new political frameworks that are governed by historic economic events and led by a set of emerging trade policies. This set of social and historical forces demand the improvement of the current and subsequent economic organizations. Government agencies now follow the instruction of new economic and entrepreneurial commands where institutionalized markets and business rule, hopefully driving the economy according to international trends, some determined by global institutional mandates like these originating from the World Trade Organization-WTO, and others more difficult to define, which lead nation-states to depart along unexpected dependent paths.

Powerful trading partners are orienting trade and investment currents through an innovative process governed by new trade and investment practices. These rules can be categorized among three generally observed pattern changes introduced by trends and cycles, departures that mark history as a more coherent world-system that is historic, economic and entrepreneurial in its commitments, as suggested by Chase-Dunn y Grimes (1995: 388).

Firstly, Wallerstein (1974), in his work The Modern World-System, put into perspective an interesting view for a new historical scenario for world business expansion. Based on characterized past events, he found that a set of nations made a single and cohesive commercial unit like the European Nations. Common interest on exchange and coincid- 
ing trade profiting practices allowed some northern European nation-states to become interdependent economic units, forming a "world-system". This historical approach is indeed useful for analysis of initial conditions leading to the explanation of the appearance of trading blocs, for example, and history teaches us that past events under given circumstances may lead the world system to replicate scenarios where emerging events may develop into enlarging systems.

This system, built from present scenarios made out of the present circumstances, allows us to understand why the world trading economy enlarged after following a process of open market transactions, market integration agreements, and institutionally created profit transactions, that later developed into a world made of new trading rules. These created conditions for the present, and encouraged the spread and distribution of trade profits allocated around the world according to priorities. This enlarging world market system or "trading area" follows "a progressive trend", making of this a dependent path that converts into an interdependent world economy where new opportunities accrue after a large number of firms interact, creating what we now denominate as clusters (Chase-Dunn and Grimes, 1995).

Secondly, in the field of international relations, new theories showed that the world has experienced important evolution and changes because of nation-state's interaction in a global world where egoistic nations compete for power. Competition for world political power is viewed in the realist tradition as a source of peace, while in the com- plex interdependent approach, it is assumed to become the source of business that allows for economic convergence (Carr, 1995: 9). Theoreticians in the neorealist tradition, like Waltz (1987) and Gilpin (1990), suggest that the world political economy promotes growth paths and satisfies multinationals' global interests that take advantage of the newly created economic and trading system.

A third line of viewing world economies involves the new endogenous economic growth routines, which predict events of historical significance, the evolutionary view of development promoted by trade as suggested by microeconomics analysts like Nelson and Winter (1982: 209). ${ }^{18}$ Their theoretical approach implies that large trading organization structures surrendered the business world, expanding even more trade currents. In this economic context, trade organizations developed, which led to distributing gains among trading participants in more diverse ways, as suggested by a complementary stream of viewpoints, including those of authors like North (1961), Bauer (1974), and Theberge (1968: 68-71). Powell (2001: 55) suggests that organizations develop in this emerging world, becoming transformed into industries and sectors that push $\mathrm{R} \& \mathrm{D}$ toward emerging technologies, and where industries rely more on basic university research, decentralizing research activities, and locating this research near competitive clusters.

18 The evolutionary model of economic growth fully explains the pattern of aggregate outputs, inputs and factor prices that neoclassical theory partially "explains". 


\section{Bibliographical References}

Alca. 1998-a. Estado de Avance de la Labor de los Grupos de Trabajo del Alca.

Amin, Ash, and Trhift, Nigel. 1995. Globalization, Institutions and Regional Development in Europe. s. 1., Oxford University Press.

Anzola Gil, Marcela; Caballero Sierra, Gaspar, y Corral Strassmann, Luis Carlos. 2002. De la OMC al ALCA: bases para la negociación. Bogotá, Colegio Mayor de Nuestra Señora del Rosario.

Axford, Barrie. 1996. The Global System Economics, Politics and Culture. Oxford, Polity Press.

Axworthy, Lloyd. 2000. Permanent Council of the Organization of American States- OAS, Washington, 11 February.

Bauer, Peter. 1974. Dissent on Development. London, McMillan.

Bhagwati, Jagdish. 1997. "Fast Track to Nowhere", in: The Economist, October 18, p. 22.

Blanco, Herminio, and Zabludovsky, Jaime. 2003. Alcances y límites de la negociación del Acuerdo de Libre Comercio de las Américas, s. 1., Banco Interamericano de Desarrollo-Intal-ITD-STA.

Bretherton, Charlotte, and Ponton, Geoffrey. 1996. Global Politics. Oxford, Blackwell's.

Cano, Carlos Gustavo. 2003. El agro de cara al TLC, Bogotá, República de Colombia, Ministerio de Agricultura y Desarrollo Rural.

Carr, E. H. 1995. The Twenty Years Crisis. 19191939. London, Papermac.
Chase-Dunn, Christopher, and Grimes, Peter. 1995. "World-System Analysys", in: Annual Review of Social Studies. v. 21, pp. 387-417.

Cipolla, Carlo M. 1991. Entre la historia y la economía-introducción a la historia económica. Barcelona, Crítica.

Comunidad Andina. 2002. Bases para la presentación de ofertas en los grupos de negociación del ALCA. SG/dt 192.

Devlin, Robert. Antoni Estevadeordeal. 2001. What's New in the New Regionalism in the Américas? Intal-Itd-Sta. Working Paper 6.

Dussel Peters, Enrique. 1997. Pensar globalmente y actuar regionalmente. México, UNAM.

Foreman-Peck, James. 1995. Historia económica mundial, Madrid, Prentice Hall.

Free Trade Area of the Americas. 2003. Eighth Ministerial Meeting. Miami, Ministerial Declaration. Available Fromm: http://www.ftaa-alca.org/ Ministerials/Miami/Miami_e.asp

Friedman, Thomas L. 1999. The Lexus and the Olive Tree, New York, Anchor Books.

Fukuyama, Francis. 1991. El Fin de la Historia. Planeta. Barcelona.

GAO-United States General Accounting Office. s. f. Free Trade Area of the Americas-Negotiators Move Toward Agreement That Will Have Benefits, Costs to U.S. Economy. GAO-01-1027. Washington.

Gil, Julio César. 2001. "La Comunidad Andina ante el ALCA: implicaciones y oportunidades", in: 
SELA. XXVII Reunión Ordinaria del consejo Latinoamericano, Caracas, 8-10 de octubre.

Gilpin, Robert. 1990. La economía política de las relaciones internacionales. Buenos Aires: Grupo Editor Latinoamericano.

Guilhon Albuquerque, José Augusto. 2003. "Los desafíos del futuro gobierno de Lula", in: Foreign Affairs. En Español, v. 3, n. 1.

Hearing of the Trade Subcommittee of the House Ways and Means Committee. June 13, 2003.

Held, David. 1995. Democracy and the Global Order, Stanford, Stanford University Press.

Hinsley, F. H. 1967. Power and the Pursuit of Peace, Cambridge, Cambridge University Press.

Holton, Robert J. 1998. Globalization and the Nation-State, London, MacMillan Press.

Huntington, Samuel P. 1996. "The West: Unique, Not Universal”, in: Foreign Affairs, NovemberDecember.

Kenwood, A. G., and Lougheedd, A. L. 1998. The Growth of the International Economy, London, Routledge.

Le Goff, Jacques. 1991. Pensar la historia. Modernidad, presente, progreso, Barcelona, Paidós.

Lewis, Anthony, and Lewia, Paul G. 1992. Global Politics. Oxford, Polity Press.

Michie, Jonathan, and Grieve, John. 1995. Managing the Global Economy, Oxford University Press.
Miles K. Light. Acuerdo de Libre Comercio de las Américas: Impactos Económicos en la Comunidad Andina. 11 de Septiembre de 2003. Secretaría General de la Comunidad Andina.

Moore, Mike. 2000. Back on Track for Trade and Development, Speech give by the Director General of the WTO at the X Meeting of UNCTAD held in Bangkok on 16 February.

Musbach, Richard. 1997. The Global Puzzle. Boston, Hougton Mifflin Co.

Nelson, Richard R., and Winter, Sidney G. 1982. An Evolutionary Theory of Economic Change, Cambridge, Harvard University Press.

North, Douglas C. 1961. The Economic Growth of The United States, 1790 to 1860, New Jersey, Prentice Hall, Englewoods Cliff.

North, Douglas C. 1998. Institutions, Institutional Change and Economic Performance. Cambridge. Cambridge University Press.

O’Donnell. Guillermo. 1996. Another Institutionalization.

Parker, Geoffrey. 1998. Geopolitcs. Past, Present and Future, London, Pinter.

Parks. E. Taylor. 1970. Colombia and the United States: 1756 - 1934. Arno Press Nueva York.

Powell, Walter W. "The Capitalist Firm in the Twenty-First Century: emerging Patterns in Western Enterprise" in Di Maggio, Paul. 2002. Twenty-First-Century Firm.

Randall, Stephen. 1992. Aliados y Distantes. TM Editores - Uniandes. Bogotá 
Rawls, John. 1975. The Theory of Liberty. Oxford University Press. Oxford

Robert, Maryse. s. f. Resources and Tactics as Determinants of Negotiation Outcome: Canada's Performance in Nafta. Ph. D. Thesis. Fletcher.

Rocha, Ricardo; Perilla, Juan Ricardo, y López, Ramiro. 2003. Una aproximación de la política comercial estratégica para el ingreso de Colombia al ALCA, Documento CEDE 20003-01. ISSN-1657-7191.

Rugman, Alan. 2000. The End of Globalization. London, Random House.

Salazar-Xirinachs, José María y Robert, Maryse. 2001. Hacia el libre comercio en las Américas, Washington, Brookings-OEA.

Schott, Jeffrey J. 2001. Prosepcts for Free Trade in the Americas. Institute of International Economics-IIE. Washington.

Scholte, Jan Aart. 2000. Globalization. A Critical Introduction. London, Palgrave.

Schwartz, Herman M. 2000. States vs. Markets. New York, St Martin's Press.

Shannon, Thomas R. 1996. An Introduction to the World-System Perspective. Londres, Westview.

Sombart, Werner, 1929. "Economic Theory and Economic History", in: The Economic History Review, v. II, n. 1, enero, p. 1.

Special Summit of the Americas. Declaration of Nuevo León, Monterrey, México. January 13, 2004. Available from: http:/www.ftaa-alca.org/ Summits/Monterrey/NLeon_e.asp
The U.S. Bilateral Free Trade Agreements With Chile And Singapore. Headline: Hearing Of The Trade Subcommittee Of The House Ways And Means Committee. Subject: Implementation Of The U.S. Bilateral Free Trade Agreements With Chile And Singapore. Chaired By: Representative Philip M. Crane (R-Il). Location: 1100 Longworth House Office Building, Washington, D.C.

Theberge, James. 1968. Economics of Trade and Development. s. 1., John Wiley and Sons.

Umaña, Germán, et al. 2003. Análisis del Tratado de Libre Comercio Chile-Estados Unidos, Comunidad Andina, Documento de Trabajo. SG/dt 221. 19 de junio. 2.23.

Wallerstein, Immanuel. 1980. El moderno sistema mundial II, México, Alianza.

1974. The Modern World-System, New York, Academic Press.

Walters, Malcolm. 1995. Globalization, London, Routledge.

Waltz, Kenneth N. 1987. Teoría de la politica internacional, Buenos Aires, Grupo Editor Latinoamericano.

Weintraub, Sidney. 2004. "The Monterrey Hemispheric Summit", in: Issues in International Political Economy, No. 49, January.

\section{On line:}

http://www.ftaa-alca.org http://www.ftaa-alca.org/tnc18s.doc http://www.ftaa-alca.org/tnc18s.doc. Anex II. 